Article

\title{
Social Value Creation and Social Innovation by Human Service Professionals: Evidence from Missouri, USA
}

\author{
Monica Nandan ${ }^{1, *}$, Archana Singh ${ }^{2}$ D and Gokul Mandayam ${ }^{3}$ \\ 1 Social Work and Human Services, Kennesaw State University, Kennesaw, GA 30144, USA \\ 2 Centre for Social Entrepreneurship, Tata Institute of Social Sciences, Mumbai 400088, India; \\ archana.singh@tiss.edu \\ 3 School of Social Work, Rhode Island College, Providence, RI 02908, USA; gmandayam@ric.edu \\ * Correspondence: mnandan@kennesaw.edu
}

Received: 25 June 2019; Accepted: 29 October 2019; Published: 8 November 2019

\begin{abstract}
Owing to the contextual challenges, human service professionals (HSP) are creating social value (SV) for diverse vulnerable population groups through social innovation. This qualitative exploratory study investigates the nature of SV created by 14 HSPs, representing a diverse range of human service organizations (HSOs), and examines 'why' and 'how' they innovate. In addition, the study examines HSPs' current understanding and practices related to social entrepreneurship (SE). The study findings highlight that increased accountability and new funding opportunities challenged HSPs to innovate. HSPs created SV by addressing new unmet needs, developing new collaborations, and employing alternative marketing strategies, thereby ensuring the financial sustainability of their programs and organizations, and promoting social and economic justice. Different understandings of SE were voiced based on the educational backgrounds of HSPs. Without formal training in SE, HSPs trained in social work appeared to use various components of the SE process, though in a haphazard fashion compared to those with a non-social work academic training. We suggest that the graduate curriculum across various disciplines should formally include principles and behaviors related to social innovation and entrepreneurship. Finally, more research is needed to understand and describe how HSPs create SV in HSOs.
\end{abstract}

Keywords: social value creation; social innovation; social entrepreneurship; resource mobilization; collaboration; opportunity recognition

\section{Introduction}

Over the past few decades, human services organizations (HSOs) in the nonprofit sector have been facing unprecedented contextual challenges. For instance, HSOs are experiencing a reduction in access to traditional funding sources, growing competition for existing resources and capital (financial, human, physical), increasing demands for services due to market and public sector failures, and growing complexity of beneficiaries' needs (Boris et al. 2010; Jarman-Rohde et al. 1997). In order to survive in this dynamic environment, practitioners and organizations need to "leave their comfort zones, experiment, and try new ideas" (cf. Kotter 2012). Relying predominantly on any single source of funding, especially governmental, creates sustainability issues for social programs and limits their ability to create social value (Fawcett and South 2005; Mulroy and Shay 1997; Stoesz 2011).

Within the aforementioned challenging context, HSOs are being called upon to demonstrate worth and sustainable impact in an equally unprecedented fashion (Martin and Osberg 2007). Consequently, some HSOs are being socially entrepreneurial and innovative for creating social value and impact (Nandan et al. 2019; Phills et al. 2008; Schmitz and Scheuerle 2012). Globally, the growth in social 
entrepreneurship is impacted by increasing wealth disparities, corporate social responsibility initiatives, market, institution and state failures, technological advances, pressure on nonprofits to be innovative, and greater alliances between nonprofit and for-profit sectors (Jiao 2011). The purpose of this study was to investigate the nature of social value created through social innovation by entrepreneurial human service professionals (HSPs) in nonprofit HSOs.

Social entrepreneurship (SE) is comprised of five complex levels, including "social value creation, social entrepreneur, social entrepreneurship organization, market orientation, and the process of social entrepreneurship" (Greblikaite et al. 2015, p. 378). Creating social value (SV) through social innovation (SI) and strategizing is central to the SE process (Lehner 2011). It is created "by improving the well-being of disadvantaged individuals" and can be measured by the organization's output of societal benefits or the reduction of a societal need (Kroeger and Weber 2014, p. 514). Duke University's definition of SE includes "the process of recognizing and resourcefully pursuing opportunities to create social value with the innovative method. Social entrepreneurs are innovative, resourceful, and result-oriented, who draw upon the best thinking in both business and nonprofit worlds to develop strategies that maximize social impact" (Jiao 2011, p. 133). SI creates social impact through novel solutions that are "more effective, efficient, sustainable, or just than existing solutions," and the benefits accrue to society more than to private individuals (Phills et al. 2008, p. 36).

Organizations that perceive threats in the environment are more likely to be innovative in order to survive and create innovative competitive strategies to create social value (Weerawardena and Mort 2012). Interestingly, the SE process has been used to varying degrees within the nonprofit sector (e.g., social movement and social advocacy organizations) without necessarily labeling the efforts as being socially entrepreneurial (Roper and Cheney 2005). While there is some (mostly qualitative) research on the characteristics of and motivators for social entrepreneurs, impact of social innovation, and some international studies on the process of social value creation, we were unable to identify studies on HSOs where all three related concepts were examined. This study bridged some of the gaps in the HSO literature by exploring how HSPs created social value through social innovation, and by examining their understanding and practices pertaining to social entrepreneurship.

\section{Literature Review}

In this section, following the conceptual definitions of HSOs and HSPs, the authors describe the key variables of SV, SI, and SE. Hasenfeld (2015), defines human service organizations (HSOs) as entities (formalized groups of people who carry out practices) that: (a) offer services to clients from vulnerable population groups; (b) honor and promote clients' self-worth; (c) give voice to the marginalized and disadvantaged population; and (d) advocate for stronger social rights through political action. He believes that, in order to embed these practices within a supporting organizational structure, hierarchical relations are minimized, power is equally distributed among the staff, and the clients have a major say in setting organizational policies. Furthermore, he argues that HSOs struggle with balancing the ever-growing, complex needs of vulnerable populations on the one hand, and ensuring the optimization of revenue and sustained growth on the other. Furthermore, HSOs can operate under different auspices, i.e., nonprofit, for-profit, and public/government, and, depending on their mission, address a variety of social problems (Gibelman and Furman 2008).

Gibelman and Furman (2008) describe human services professionals (HSPs) as being the integral workforce of human service organizations (HSOs), often assuming the roles of direct service workers, managers, administrators, and other employees serving clients. HSPs, trained in various fields (e.g., human services, social work, public administration, counseling, etc.), meet the needs and improve the overall quality of life of individuals, families, groups, and communities, through the prevention and remediation of problems (National Organization for Human Services (National Organization for Human Services ) NOHS).

Against this backdrop of HSOs and HSPs, there is great variability in the definitions and conceptualization of the social entrepreneurship process, social innovation, and social value creation. 
Joseph Schumpeter's and Israel Kirzner's classical theories of entrepreneurship apply to SE. Using entrepreneurial thinking, social entrepreneurs rely on intuition and discovery to identify opportunities for proactively solving problems. The SE process is not the same as leadership and management abilities and processes; SE cuts across sectors and boundaries, and the SE process creates lasting system changes in the social sector. Therefore, the study of the SE process is as important as the study of the individual entrepreneur (Shockley and Frank 2011).

Following an extensive review of the literature on social innovation, value creation, and SE, Choi and Majumdar (2013) described social value creation as a large concept that can be implemented or operationalized through social innovation and SE processes used by social entrepreneurs in SE organizations. The conceptual framework has four circles intersecting with each other in a Venn diagram-social innovation, social entrepreneur, SE ventures, and market orientation-to ultimately create social value. We examined the relationship between three of the concepts from Choi et al.'s framework—social value creation, social innovation, and social entrepreneurship-in human service organizations.

Similar to social entrepreneurs, HSPs also solve social problems and create social value; however, they may not create a new organization (social entrepreneurship venture) in the process. Recognizing the similarity between social entrepreneurs' and HSPs' goal of social value creation, and the difference in their organizational context, we used Choi and Majumdar (2013) framework to understand how HSPs create social value within the context of HSOs. The social entrepreneurship process is one of several ways of creating social value. Therefore, it is important to understand whether or not HSPs use entrepreneurial approaches to solve social problems and create SV innovatively. It is also important to gauge their understanding of social entrepreneurship.

\subsection{Social Value Creation}

Unfortunately, there is no consistent understanding of social value creation within the SE literature (Dees et al. 2001; Mair and Schoen 2007). Innovativeness, proactive behaviors, and risk management are important predeterminants of social value creation (Weerawardena and Mort 2006). Cross-sector alliances can create SV that would not have been created individually by either party acting alone, because they bring complementary resources to the table and address challenges in a way that would not be possible for any single entity (Caldwell et al. 2017). The research on social innovation conducted by Altinay et al. (2016) revealed six themes within social value creation: natural; financial; political and institutional; human capital; stakeholder collaboration and involvement; and the development of relationships leading to community member empowerment. Social value creation can be "reputational and ethical" in nature as well, especially in large nonprofit organizations such as the American Red Cross and Greenpeace USA, which have sustainable business models, based on their reputation and ethical residuals, that motivate charitable giving (Auerswald 2009, p. 53). Kuratko et al. (2017) propose that value creation requires constant adaptation to the changing environment.

The total social impact created by HSOs for all stakeholders can be labeled as social value creation (Polonsky and Grau 2008). Social value is created when social entrepreneurs bring about a "range of desired social changes or social impacts" (Singh 2016, p. 109). Singh's research in India revealed that social entrepreneurs created SV by impacting beneficiaries in the following ways: increasing their awareness levels on key issues, creating empowering environments for them, ensuring that their socioeconomic needs were met, and changing perceptions, attitudes and behaviors, and even norms. SV can also be created when alterations are made to a context's structure and process (Singh 2016, p. 110), or when needs are met at different system levels (Seelos and Mair 2005). Similarly, in another study in India (Sundaramurthy et al. 2013), the findings revealed three forms of social value creation: market makers-where beneficiaries are involved in the business model of the enterprise, creating jobs in the community; system innovators-implementing system level innovation that caters efficiently to serving the disenfranchised populations; and innovative campaigns-providing education and raising 
awareness among beneficiaries to create social value and change. Operationalizing and measuring social value creation still remain a challenge.

Nevertheless, the balanced scorecard (BSC), based on the impact model, is one method of measuring the impact or value, taking into account the resources placed within the activity to generate goods and services. The BSC is split into three sections: output, including financial, customer, learning and growth, and internal processes; outcome, including infrastructure development, human condition, market share, and benefactor support; and impact, including social economic change, environmental change, venture sustainability, and policy change (Clark and Brennan 2016). Social return on investments-though with some shortcomings-is another method to measure social value (Ormiston and Seymour 2011). Social, environmental, and sustainability reporting, which come in the form of a global reporting initiative or a triple bottom line approach, are additional methods to measure value creation (Gray 2006). Notwithstanding these measurement tools, few organizations appear to be employing strategies to measure impact (e.g., Clark and Brennan 2016).

\subsection{Social Innovation (SI)}

The literature on social innovation publications was sparse before 2003. However, scholars in the field of urban and regional planning were writing on community-based social innovation, well before the concept emerged within the entrepreneurship and management disciplines (Van der Have and Rubalcaba 2016). SI is not limited to one type of organization-it is found in government, community, nonprofits, corporations, and other types (Konda et al. 2015). The steady growth of the nonprofit sector, in combination with the gaps in government services that are filled by nonprofits, has created demand for innovation in this field, but there remains "limited funding, lack of key resources, dated technologies, and organizational structures that are not conducive to experimentation and creativity" (Jaskyte et al. 2018, p. 3). Jaskyte found that, while most foundations were supportive of nonprofits engaging in innovation, some placed restrictions on grantees that limited their ability to innovate.

Baregheh et al. (2009) defined innovation as a multi-staged endeavor that improves the current product or service, advances and differentiates an organization from its competitors in a marketplace, or introduces processes that improve internal performance. Innovations can fall into three categories: purely social innovations, purely business innovations, and innovations that involve both society and business (Pol and Ville 2009). The latter focuses on making a profit while improving the quality of life of the beneficiaries at macro and micro levels. The benefits can be in the form of a reduction of the cost to society or the creation of direct advantages. SI incorporates both idea generation and sustainable outcomes that are more effective, just, and efficient than existing solutions (Nikolic 2016; Phills et al. 2008). Van der Have and Rubalcaba (2016) expound the idea of bifocal innovations, in that some SIs that create SV also involve monetary exchange for services attached to them, while other forms of SI contribute to human and social life and cannot satisfy needs through the marketplace. Alternatively, Lisetchi and Brancu propose that "[s]ocial innovation refers to innovative activities and services that are motivated by the goal of meeting a social need and that are predominantly diffused through [existing or newly created] organizations whose primary purposes are social" (Lisetchi and Brancu 2014, p. 89).

Essentially, SI generally produces tangible or intangible outcomes that enhance community wellbeing (Maguirre et al. 2016), but if SI is not suitable or sustainable for an organization, it could cause that organization's downfall.

Building relationships, maintaining partnerships, and combining capabilities and opportunities in novel ways all contribute to the design and implementation of SI, because the locus of SI is in the social system, not an organization or person (Phillips et al. 2015). SIs that result from community-based collaborations build on community strengths and partner with final beneficiaries to effectively solve social problems (Mulroy and Shay 1997). In other words, SI often requires engaging citizens and various individual and institutional stakeholders in the creation of innovative ideas and for effective implementation at all levels (Herrera and Elena 2015; Lisetchi and Brancu 2014; Rao-Nicholson et 
al. 2017). Herrera and Elena (2016) examined the impact of SI in bridging the social divide caused by inequality and inequity. SI was influenced by the process, leadership, stakeholders, and other partner organizations involved in the issue. Additionally, co-creating socially innovative solutions was essential for addressing the social divide and achieving integrated growth.

Innovation is not without risks and challenges that are beyond the financial in nature-e.g., the vulnerability of the populations served by the innovative intervention, a lack of supportive environment, regulatory frameworks, the unwillingness of state agencies and other actors to make changes, and a scarcity of financial and nonfinancial resources (Brown 2010; Konda et al. 2015). Risks can be taken in the form of "affordable loss," which refers to an individual's own estimation of what they might be able to put at risk, and also a determination of what they are willing to lose in order to plunge into entrepreneurship (Dew et al. 2009). Brown (2010) examined four U-K and Australia-based public sector agencies that engaged in risk-taking during the innovation process. Based on the findings, she concluded that organizations need to engage in "positive risk-taking" and reassure stakeholders that risks can be well-managed; social entrepreneurs cannot engage in mistake-free innovation. She recommends that there "needs to be an explicit recognition by government that they are aware of the risks involved in innovating in this context and that they are prepared for local authorities and voluntary organizations to take on the risks that innovation will pose. Until then, the gap between the policy ambition and reality in practice remains potentially great" (p. 1224).

The last two studies illuminate that SI entails satisfying human needs that are currently unmet, creating change in social relationships (e.g., between local communities and government), and contributing to the empowerment of beneficiaries by increasing socioeconomic capabilities and enhancing access to resources (Moulaert et al. 2005). They also illustrate social innovators who not only generate new ideas, but also change the larger context so that innovation can flourish (Moore and Westley 2011).

\subsection{Social Entrepreneurship (SE)}

Social entrepreneurs are individuals or groups of individuals who are change agents, forging innovative solutions for recalcitrant social problems by using the SE process (Rego and Bhandary 2006). Several authors (e.g., Dacin et al. 2010; Jiao 2011; Short et al. 2009) have analyzed the SE literature to create typologies of the definitions, and conclude that it is complicated to conceptualize and explain this perspective. Differential foci of definitions relate to sector, organizational form (e.g., social enterprise is equated to SE), process, mission and motive, and social change creation. In some SE literature, social enterprises are equated with SE-the social enterprise school—and in others, SE is equated to social innovation-the social innovation school. Both schools of thought speak to the necessity for fresh approaches to address social problems (Dees and Anderson 2003). SI and SE interface at various levels and relate as follows: "If social innovation involves meeting an unfulfilled need with a view to create system change, then social entrepreneurship is its actualization: it creates change and makes a difference" (Rao-Nicholson et al. 2017, p. 4).

The SE movement was first identified in the 1980s and has grown steadily. The National Center for Social Entrepreneurs (founded in 1985) offers a variety of education and consulting services to entrepreneurs in the nonprofit sector. Zietlow (2001) credits Dees (1998) for the five defining activities of social entrepreneurs: "adopting a mission to create and sustain social value," "recognizing and relentlessly pursuing new opportunities to serve that mission," "continuous innovation, adaption, and learning," "acting boldly without being limited by resources," and "exhibiting a heightened sense of accountability to the constituencies served" (Zietlow 2001, p. 20).

Another theoretical perspective is offered by Zahra et al. (2009), who categorize social entrepreneurs into three groups, each at different levels. Social bricoleurs are able to identify specific social needs that have gone unrecognized and "derive their power to act from being in the right place at the right time, as well as possessing the skills to address the needs," and knowledge that is specific to the local community (p. 212). Social constructionists identify and pursue opportunities centered around 
creating social wealth, pursuing broad social issues. They possess a unique capacity to do so, rather than having community-specific knowledge. Finally, social engineers create drastic change when "compelling social needs are not amenable to solutions within existing institutions" (p. 214). Similar to Choi and Majumdar (2013), these authors emphasize that the purpose of SE is social value creation.

SE perspective is about opportunity recognition, innovating, meeting a social need, taking calculated risks, and being proactive while maintaining the financial sustainability of the organization that is delivering the innovative idea. Opportunities for innovating are often embedded in context; the organization's mission, barriers in the social market, and the social entrepreneur's background can influence how the SE process unfolds (Corner and Ho 2010).

Harding (2007) compared the characteristics of social entrepreneurs within social enterprises in the UK to those of commercial entrepreneurs. Similar to Singh (2016) findings in India, the UK entrepreneurs were less confident about their business endeavor, though less fearful of failure, and often knew someone who was an entrepreneur. Older individuals from different ethnic backgrounds were more likely to be social entrepreneurs than their white counterparts. She also found that training in entrepreneurship greatly enhanced the chances of individuals engaging in SE. In a longitudinal study conducted by Perrini et al. (2010) that explored the SE process in terms of distinct stages and factors in the enterprise's development, the variables that impacted the formation and scaling of the enterprise included social opportunity recognition, evaluation of the opportunity, ensuring value creation that has a lasting impact, ensuring sustainability, innovation to create impact, using networks to form the social enterprise and scale it, institutional context, the level of competition in the social sector, and the presence of a role model for the social entrepreneur.

Related to this study, Alvord et al. (2004) examined seven successful SE cases to identify factors correlated with their success. They explored the nature of the innovation, the characteristics of the leaders, the organizational structure, and the paths they chose to scale up the impact. The goals of the organization influenced the range of social innovation initiatives. Most organizations collaborated closely with the local community to build capacity. Leaders demonstrated moderate to high ability for developing bridge capacity. Scaling-up also varied across the cases, influenced by the type of innovation. Social entrepreneurs first strengthened the capacity of the group and the village before expanding it to include client groups not initially covered by the innovative service.

In conclusion, studies on social value creation, social innovation, and social entrepreneurship exist across the globe, but no study appears to have examined all three related concepts (Choi and Majumdar 2013). SE studies are more about characteristics and motivators for social entrepreneurs, not about their understanding of SE, nor about how they create SV through innovation. Additionally, there is inadequate research on how SI takes place in various environments (Rao-Nicholson et al. 2017), and how SI addresses complex and dynamic issues (Van der Have and Rubalcaba 2016). Also, there is a limited understanding of how HSO professionals from different disciplines create SV through SI (Sensoy Bahar 2017). Moreover, as mentioned earlier, content on identifying, describing, and measuring social value created by social entrepreneurs is lacking in the literature (Ormiston and Seymour 2011; Pärenson 2011). Without being able to articulate the impact and value, nonprofit organizations will not be able to attract different forms of funding and revenue streams. This study proposes to add to the conceptual framework that examines the relationship between social value creation, SI and SE. Using the systems framework, the purpose of the present study was to address three research questions:(1) Why and how do HSO professionals innovate in the process of social value creation and service delivery? (2) What is the nature of social value created by HSO professionals? (3) What is HSO professionals' understanding of social entrepreneurship?

\section{Method}

This exploratory descriptive study was conducted in a metropolitan city in Missouri, USA, where the executive director (ED) of a training center for nonprofits was asked to provide a list of nonprofit HSOs where practitioners would be regarded as being socially entrepreneurial. This 
particular ED trained nonprofit managers in social entrepreneurship processes. His list was vetted by a consultant affiliated with the center, who was a faculty member at a local university and trained social entrepreneurs in a graduate program, in addition to serving on national organization boards advising on social entrepreneurship. Thirty potential participants constituted the nonprofit HSO sample frame. Emails were sent to all 30 potential participants, inviting them to participate in the study. Fourteen participants responded to the email and face-to-face interviews were scheduled with each, where a semi-structured interview format was used with 14 questions (Given 2008; Patton 2001).

Patton (2001) recommends that exploratory research should employ open-ended, semi-structured interviews, where the questions are amenable to modifications based on the context and ability of the respondents to answer. This allows the interviewer and interviewee to have more of a conversation on the subject while collecting reliable and comparable qualitative data for cross-case analysis. This method also allows respondents the freedom to express their views in their own terms, while allowing the researcher to guide and control the conservation (Given 2008).

Interview questions were drafted based on the literature on SE, SV, and SI. These questions were primarily related to understanding the impact of contextual changes on service delivery and financial feasibility of the programs; coping strategies, adaptation, and innovation to deal with the challenges; their understanding of being innovative, creative, financially feasible, taking risks, and/or being economically self-sufficient in social ventures; their own ways of addressing social problems or serving the public good; strategies employed to reduce financial uncertainties; social mission; their understanding of the concept and practice of social entrepreneurship. These questions were shared with the aforementioned consultant for feedback and review. All subjects gave their informed consent for inclusion before they participated in the study, and the study was approved by the mentioned university's institutional review board. Interviews were taped and transcribed, verbatim. Transcripts were sent back to the respondents to check the content validity, and each transcript was written up as a case study.

Content analysis was completed on each case by two of the researchers, using coding with indigenous concepts (Patton 2001). Subsequently, cross-case analysis was completed to identify themes using sensitizing concepts (Patton 2001) from the conceptual frameworks of social value, social innovation, and social entrepreneurship. Based on the diversity of characteristics represented in the sample-academic preparation of respondents, role of respondent, size of the HSO in terms of budget, and types of services provided-the authors decided, post hoc, to examine differences in the responses to the 14 questions based on academic preparation of respondents only. The sample's distribution precluded meaningful comparisons across all other HSO characteristics. For instance, the list contained only one therapist. Moreover, in the USA, research on social entrepreneurship has primarily originated in the public administration, nonprofit management and business fields; these studies have typically not examined the impact of disciplinary differences on social entrepreneurship practice and process. Though more recently, there has been some scholarly activity in the social work field related to SE, SV, and SI (e.g., Nandan et al. 2019). Consequently, based on the academic background of respondents, authors grouped the sample into social work and non-social work categories.

The sample consisted of 10 nonprofit professionals with social work degrees and four with degrees other than social work - a law degree, Master's in business administration, an undergraduate degree in business finance, and a graduate degree in education. Organizations represented by the sample of human service professionals (HSPs) with a social work degree were mental health, adult daycare, group practice, group home for boys, respite care for parents of ailing children, advocacy services for women and children, domestic violence, children services, advocacy for sexual assaults, and a healthcare foundation. Annual budgets of these organizations ranged from $\$ 100,000$ to $\$ 45$ million. HSPs were either program directors, CEOs, therapists, family specialists, or case managers. Organizations represented by the sample of professionals with a non-social work degree included an advocacy organization, an agency that conducts information systems training, a dental care supply organization, and a consulting organization that teaches nonprofit and management leadership skills. 
The annual budgets of these organizations ranged from $\$ 470,000$ to $\$ 1.4$ million. These HSPs were a $\mathrm{CEO}, \mathrm{COO}$, or executive director.

\section{Results}

Themes that emerged from conducting the cross-case analysis were grouped into four categories that speak to each of the research questions. Within each of these categories, additional themes emerged that exemplified the various dimensions of the main category.

\subsection{Change in Context and Challenges for HSOs and HSPS}

Contextual changes created challenges and opportunities for HSPs, and their responses varied based on the services they provided and the stakeholders in their network. HSPs trained in the social work and non-social work fields exhibited a different emphasis in their response to the challenges. HSPs trained in social work focused more on the increasing accountability while those trained in other fields focused more on reductions in funding opportunities.

\subsubsection{Increased Accountability}

The dynamic "intersectionality" of the economic, political, social, and demographic spheres significantly impacted human service delivery and created both challenges and opportunities for HSPs. For example, a downturn in the economic conditions, high levels of dependency on small donors, and changing criteria and expectations of the funders/donors influenced almost all cases. Owing to the economic downturn, people lost jobs, which created multiple new problems and needs within families and communities. The funding organizations modified their criteria for awarding grants and funds, requiring business plans, impact statements, measurable outcomes, and long-term sustainability outlook, while also reducing recurrent funding of projects. Most HSPs with social work training confessed that they were ill-prepared to meet these requirements and expectations from grantors and philanthropists.

We really have to be much more accountable in how we are spending the money.... They want to know that their investment [not donation] was a worthwhile investment. So you have to have outcomes that are tied back to that ... they are very measurable and objective. (Participant \#5)

\subsubsection{Funding Opportunities}

HSPs trained in other fields alluded to the aforementioned challenges, but placed a great emphasis on the reduction in funding.

One of the things that has happened in the last five years ... across the county is that funding for that kind of social justice sentiment is significantly drying up in America. (Participant $\# 11)$

\subsection{Social Innovation for Social Value Creation}

The HSPs trained in social work used different innovative strategies not only to meet the existing needs, but also to identify new unmet needs and create social value. These innovations became necessities for the continuous service delivery process in the challenging environment. Five subthemes emerged related to social innovations for creating social value.

\subsubsection{Identification of New Unmet Needs and Social Innovation}

HSPs trained in social work were continuously vigilant of new emerging unmet needs. One respondent identified new unmet needs through consumer feedback. 
Again we are having to be more creative in identifying the needs of the clients and then addressing those needs with not necessarily an increase in funding to come with that. For example, we started the Guardian program ... we started this, $4 \ldots 5$ years ago. And that is a Safe Visitation program. And we started that program as a direct result of our clients telling us through our feedback processes-feedback surveys that we ask them to do, when they leave services or every few months we ask them what their needs are, in their group [therapy], counselling sessions. (Participant \#5)

\subsubsection{Collaboration, Partnership, Networking and Social Innovation}

HSPs trained in social work were using collaboration, partnership, and networks to enhance social impact, meet more needs within communities, manage space constraints, ensure task completion without additional cost, and sustain programs during difficult financial times. Participants also provided additional services by networking with other agencies.

If we are unable to take them into our facility, then our job is to have this network of groups that we are working with to help them get the services that they need. Other agencies ... that can house them ... translation services. (Participant \#5)

Another HSP trained in social work employed parents as partners in a group home setting.

The other unique piece of our Home is that we do not take custody away from the parents. We refer to parents as partners [and kids have to apply to get in]. (Participant \#2)

Partnership was used innovatively to ensure the financial stability of the program.

We partnered with them [local thrift store] for a certain amount of money every month. They pick up donations and they sell them at their thrift store. We don't have to operate the thrift store and we don't have to have any of that liability. We get a certain amount of [guaranteed] money every month. If we do it over a year, it could be close to $\$ 120,000$. And we don't have to do much. (Participant \#7)

The respondent clarified that people donated so much to the shelter that they could not possibly use. Consequently, they shipped the donations to the thrift store, which sold the goods and provided cash to the shelter almost like a guaranteed income. Collaborations were also used innovatively to provide more benefits to the clients.

Day to day, we are doing innovative things. Wherever we can empower family members of clients who attend, both just at a self-sufficiency level and at a financial level, that's what we try to do. Collaborations with other organizations. (Participant \#3)

HSPs trained in disciplines other than social work indicated the same need for networking and collaboration for innovatively responding to new needs, while minimizing risks and enhancing financial viability for creating social value.

We are partnering with people who help us to minimize the risk by sharing the responsibility and commitment, financial and/or personnel.... [I]t's thinking outside the box and it gives us a lot of freedom to define and redefine, adapt, implement and change as we need to meet the [needs of] communities we are touching. (Participant \#12)

This respondent networked with community residents to start a social enterprise-a greenhouse where the at-risk youth were trained to grow plants, make flower arrangements, and sell these products at various outlets-aimed at enhancing employment (or entrepreneurial) skills of the population as well as generate revenue for the organization. 


\subsubsection{Resource Mobilization and Social Innovation}

The financial crisis created resource mobilization challenges for HSPs, limiting their ability to sustain or expand services. Notwithstanding these challenges, HSPs trained in social work innovatively mobilized resources such as volunteers and interns for service delivery. Due to the severe financial strain at one agency, Participant \#3 hired 20 volunteers to sustain the operation; two other respondents (Participants \#2 and \#5) recruited over 50 volunteers to deliver services in a youth group home, and recruited interns from different disciplines (e.g., social work, counseling, etc.) to provide clinical counseling to clients in a domestic violence shelter.

Similarly, some participants employed innovative strategies to mobilize alternative resources in lieu of cash donations. One HSP invited partners to donate their skills in volunteer hours for services needed by the organization (e.g., construction, legal advice) and by clients (e.g., hairdressing, nail care, etc.). Another participant used 'partnerships' for bartering in order to deal with the financial challenges.

You have to be as creative as possible and you partner with people and [you say to people] "[if] you can't give me cash, can you give me this ... " Really get creative about our partnerships and still get what we need, and yet it helps them [the giver]. [Bartering] is very creative and very helpful ... it gets the work done. (Participant \#5)

This participant also creatively converted donations into cash for the organization.

Just for example, our food budget for the year is $\$ 15,000$ for two shelters. We served 1500 women and children last year ... We get food drives, food donations, we go to harvesters, then we go to fairs ... and we get food donated. When they are buying the hogs ... then they donate it to us. So then we are able to take that to the food processing plant and then they give us gift cards. They say 'OK, this is how much [of other meat] you had and I will translate that into $50 \mathrm{lbs}$ of ground beef' and gives us a gift card. Then when we are ready for it ... we go in and get the meat we are going to use. (Participant \#5)

Some participants were innovative in raising funds and generating revenues by starting financially self-sufficient programs, diversifying funding streams, developing systematic plans for fundraising, and starting revenue generating programs to subsidize others. Additionally, some were clearly more focused on measuring outcomes and social impact, and learning to write business plans to attract funding. One participant generated revenue by selling their service delivery model and providing technical assistance for its implementation. "We are selling our model and we are selling our technical assistance." (Participant \#3)

Interestingly, some HSPs were using partnerships for addressing space constraints for delivering services. Participant \#5, who did not have adequate space to provide services to clients, very innovatively partnered with the community by using a community building where volunteers could provide services (e.g., hairdressing, tax and legal advice) and interns could provide counseling in a more centralized and convenient location.

\subsubsection{Marketing (Promotion) and Social Innovation}

Some HSPs trained in social work understood the importance of promotion of agency for achieving social mission.

I am learning that you have to get yourself out there and people have to know about you. And, they have to know about you at two levels: first, to support you through donations in money or in kind, and second, the people you are trying to serve as well [should know about you]. (Participant \#7)

Another respondent mentioned, 
One of my colleagues ... she does a radio program once a month and reaches into the gay community and brings in clients. It is a free service, but it brings in people, her name is out there. I think of that, and that's very creative. She interviews different people in the gay community. And that's her expertise. And now she does a group once a week for people who are "coming out." And a lot of [referrals] have come from her radio program.... I don't take a lot of risks. But I do put myself out there in the community in different [ways]. (Participant \#2)

\subsubsection{Identification of New Opportunities/Markets and Social Innovation}

One of the participants (Participant \#8), engaged in educating students of middle and high-school age, realized the opportunity for educating even younger kids about sexual assault, and planned to start new forms of programming for this population. They mentioned,

We have a children's program [that] we try to do a prevention through kids.... You are starting with young, young kids, we have been looking at that. Our program [currently] has been more with middle school and teenagers. Really looking at those young kids ... which is hard to do in schools anymore because schools are so strapped for time and [to come into partnership with us]. (Participant \#8)

It appeared that they were constantly looking for new opportunities and markets in their existing social value creation processes to maximize the social impact.

Essentially, the use of innovation was evident in the whole process of social value creation by HSPs, i.e., starting from identifying new unmet needs, mobilizing resources for delivering social work services to clients, marketing, and identifying opportunities for increasing financial sustainability. One apparent distinction between HSPs trained as social workers and those from other fields was that the latter spontaneously deployed networks and partnerships to reduce risks and start a social enterprise.

\subsection{Nature of Social Value Creation}

Four subthemes emerged related to social value creation by HSPs trained in social work and non-social work disciplines.

\subsubsection{Social Mission, New Unmet Needs, and Social Value Creation}

All HSPs with formal training in social work and non-social work disciplines were deeply committed to achieving their respective organization's social mission and providing different types of services to diverse groups of clients. They created social value by meeting the needs of individuals with mental illness, mature adults who were unable to take care of themselves at home, young adults subjected to sexual assault and abuse, and uninsured and underserved individuals and communities. Others served clients indirectly by helping enhance the efficiency and functioning of HSOs. For instance, one participant (\#9) created social value by streamlining the functioning of five children and youth service agencies by: (a) centralizing the management and training of their employees, (b) centralizing the management of their financial systems, and (c) by performing back-office tasks more efficiently so that agency personnel could focus on more effective service delivery.

Directly or indirectly, all HSPs trained in social work and non-social work disciplines were creating value by impacting the lives of beneficiaries, family members, and other community stakeholders. These services need not always be unique, but must meet the unmet needs of the clients in order to be classified as social value creation.

HSPs trained in disciplines other than social work used innovative ways of meeting the needs of vulnerable population groups that resulted in social value creation and ensured sustainability of the intervention. One HSP who worked with youth addicted to drugs and involved with gangs created social value with his greenhouse social enterprise intervention that aimed at enhancing employment skills as well as generating revenue for the organization. 
We taught our drug-involved and gang-involved kids how to grow plants. We tied it back to the academic curriculum so that they could school credits for their work and they could generate revenue from the sale of those plants.... We trained the kids in horticulture and floriculture and the care and management of these plants. We would then train them in all aspects of the business of managing this greenhouse.... Our kids would complete the program and go back to their own school or if they would stay with us over an extended period, they might be placed in some of these area grocery stores as their person who handled their floral departments. (Participant \#12)

\subsubsection{Identifying New Needs during Service Delivery}

During the course of service management and delivery, sometimes respondents identified additional unmet needs and, through innovative mechanisms, attempted to meet them, thereby creating additional social value. This was particularly the case among HSPs trained as social workers in meeting the needs of families, children and the elderly, and also serving through the local foundation. One participant in a domestic violence shelter noted:

We will talk to whoever is willing to listen to us so that people will know about our services and women can access them. Educating the public about that so that they can be aware of and [recognize] signs and do something about [violence against women, children, teens etc.]. (Participant \#5)

For HSPs not trained in social work, social innovation for creating both social and economic value was important. For instance, one respondent who had developed the curriculum for a strengths-based case management model identified the opportunity for training human service professionals across various organizations in the Midwest, and created web-based online training modules as an income-generating endeavor for the organization.

We were making more money than from our original training conference.... We thought this was a service ... that has become more income-generating.... We were providing a huge service that was valuable. (Participant \#14)

Another participant identified a niche market for their core competency to generate more revenue and create social value simultaneously.

You understand your core competencies and then figure out ways to use them and apply them in the universe and not be off trying to create something that you know nothing about. (Participant \#13)

\subsubsection{Financial Sustainability}

All respondents trained in social work focused on serving clients by addressing needs; some simultaneously focused on ensuring financial sustainability of the organization or program. One respondent created a sliding fee scale model for behavioral health therapy for targeting diverse market segments.

We are all committed [to this] and to doing our own work as we work with other people. So all of us are in some kind of therapy and we are doing our own work. So there's truly a commitment to help people, but we need to help ourselves in order to do that. It's not that altruistic ... we do want to make money and we do want to provide a service, but there is a sense of wanting to do it right. (Participant \#1)

Another respondent provided services outside their social mission in order to generate revenue for sustaining the primary services for clients. 
Our goal is to end domestic violence by creating safe shelters and supportive services, and that's where we want to stay as close to our mission as we can. I do think that the thrift store is a little bit of a stretch, but then not so much, because the [money] is still coming back to help our clients. (Participant \#5)

These respondents did not lose sight of the primary purpose of the organization/program, and some recognized and tapped opportunities to ensure financial sustainability. Providing services that were affordable and accessible for their clients continued to be their core focus in value creation.

To HSPs not trained in social work, financial sustainability referred to addressing the market demand for services based on research, scaling program operations to add to funding resources, and looking at diverse sources of funding including a for-profit option and lowering program costs.

One respondent started a nonprofit organization that provides dental care for children from low-income families needing braces and other essential dental treatment. The organization created several partnerships with dentists and dental schools to conduct orthodontic screenings in various communities for assigning patients to doctors as needed. Initially, the dental treatment costs were covered through fundraising and/or were partially paid for by the patient's family. However, over time, with an increase in demand for this program, the dentists largely provided pro bono service for treating kids across various communities. The cost of fundraising surpassed the costs of dentists providing pro bono services, yielding an interesting financial sustainability model for the program.

We used to pay the doctors to treat those children, but there are so many areas around the country that wanted to start our program so those doctors in those new areas were having to help us fundraise up to $\$ 100,000$ to launch a new program because you have to be able to pay the doctors. They kept calling us and saying don't make us fundraise, don't make us donate, just let us do the work. We would rather do it for free than do all this other ... so the doctors are treating these kids 100\% for free. (Participant \#11)

\subsubsection{Role of Social and Economic Justice}

HSPs trained in social work address the diverse social, psychological, educational, material, and economic needs of community members and beneficiaries, thereby ensuring social value creation. They had a natural predisposition towards promoting social and economic justice. One participant mentioned:

Coming from the core social work value of identifying where the client is and ... helping her with what she has identified as her need [is our shelter's greatest strength]. I think that coming back to 'we look at the individual as an individual' [and] not 'all battered women are the same' because they are not. So, knowing that our services have to be flexible and fluid to meet them where they are. As we have seen in the last five years an increase in the needs, our services have responded accordingly. (Participant \#5)

Similarly, in another organization a family advocate social worker (Participant \#10) initiated ACT prep classes for youth to provide services where none existed-social work values speak to the need to create services where none exist.

Interestingly, most non-social-work-trained professionals focused on promoting social and economic justice as well. They also placed greater emphasis on ensuring sound management practices within their organizations-particularly cost-efficient and financially sustainable practices for the purpose of social value creation-as compared to the social-work-trained HSPs.

\subsection{Understanding about Social Entrepreneurship}

Cross-case analysis revealed two subthemes, one pertaining to the varied definitions of the concept and the second related to illustrations of practicing social entrepreneurship. 


\subsubsection{Defining Social Entrepreneurship}

The data revealed that all the HSPs trained in social work were familiar with the term social entrepreneurship, but their level of conceptual clarity about social entrepreneurship greatly varied. Most of the respondents (7 out of 10) identified a few different dimensions of social entrepreneurship. Emphasizing addressing community and people's needs and creativity, one participant noted,

My definition would be someone who is able to, based on community and people's needs, be able to formulate specific policy and organizational efforts to provide services. That means to provide employment and provide a service to clients to meet their specific needs. So a social entrepreneur is someone who is able to do that, to creatively, collectively provide a service that meets needs at that social level. (Participant \#2)

Another respondent aligned the definition with revenue generation.

Yes, [I am familiar with the term] and I think we do it, but not in the typical sense of the term. ... I think of SE as something that will give me [dollars, additional revenue]. That's what I think of as SE. The traditional sense of that word is that you as a nonprofit are doing something making money that a for-profit is more likely to be doing. (Participant \#9)

Yet another participant referenced risk-taking and innovation in the definition.

Social entrepreneurship-I would think what it means is organizations like ours or others that are trying to find, identifying a community need.... Trying to find a way to address those needs rather it was new and innovative services, something that might be risk taking. (Participant \#2)

Interestingly, three respondents (Participants \#1, 8, and 10) incorporated most of the important dimensions involved in social entrepreneurship's definition. For example, Participant \#10 talked about all the important dimensions of social entrepreneurship: revenue generation, innovation, opportunistic, resourcefulness, challenges, need identification as opportunities, opportunity exploitation, risk-taking, calculating risk, confidence building, teamwork, and collective efforts.

The way I look at social entrepreneurship [SE] is: clearly money is a part of it, sometimes, and I think Greg Dees would agree with it, that part of [SE] is the mindset of always being innovative, always being opportunistic, always looking for the next rock to climb. Whether you have resources or not you figure it out... You see a need, you look for opportunities, you try to figure out how to build a better mousetrap. And then you figure out if the vision and mission are good, if a need is there and then you have to figure out how to pay for it.... Good entrepreneurs, whether in the for-profit or the nonprofit world, they figure it out.... There is always risk. You have to calculate your risk.... Good entrepreneurs don't do it by themselves. They surround themselves with smart people, people a hell of a lot smarter than they are, hell of a lot more knowledgeable about ... the financial stuff. (Participant \#10)

Interestingly, most HSPs not trained in social work defined social entrepreneurship more comprehensively to include pursuing social justice in innovative ways that facilitate strategic management, a disruption in traditional thinking, going beyond the financial benefits, taking a calculated risk and learning from failures, collaborating and networking with various stakeholders, exploring opportunities and resources, and competing in the marketplace for revenue generation.

Innovation to affect positive change.... [T] here is always risk with innovation ... you learn from failure and go on. Failure is something that didn't work and so you try something else. (Participant \#14) 
Pursuing social justice in innovative ways that will employ sound management as well as innovative product and service delivery ... finding relevant new ways, different ways to provide your competency to the marketplace. Sound management means you have to have a financial plan for whatever you are going to do to take a measured risk. (Participant \#12)

\subsubsection{Practicing Social Entrepreneurship}

Similar to their varied understanding of the term "social entrepreneurship," all the participants trained in social work were practicing various components of social entrepreneurship. Based on their understanding of social entrepreneurship, they reflect on their practices that exemplified dimensions of this perspective (e.g., risk-taking, not being afraid of failure). Emphasizing the importance of innovative ideas for solving problems and creating long-term funding strategy, one respondent mentioned,

We think all of our kids will become donors someday and pay us all back [they will become taxpayers and not draw on others' taxes] for the community that contributes [to their education now]. And to think of the alternative, they will not be paying taxes but drawing taxes [while on welfare to survive] because of their substance abuse problem or their crime or whatever problem [they get themselves into]. I guess, we are entrepreneurial in a way in that you have to spend money to make money, we are spending a lot of money on these kids, but we believe that we are changing generations. (Participant \#3)

Another participant described how innovatively she designed an employment mechanism for the volunteers in the organization. She mentioned,

In all honesty, there is social entrepreneurship in Wellness and Support Advocacy program. [This] program is not designed to be an employment program [for those with mental illness], it's designed ... where the outcomes that we collect are on our end clients, our consumer ... who is our target. We have been training folks to do social service work. They are employed, they are paid. We have had an awful lot of volunteers here, [who have subsequently] got employed [with us]. This is like "Hotel California" ... you will not leave here ... With interns, you will probably end up being a volunteer afterwards and later, you are going to end up on staff. So don't even walk through the door, because you are stuck [you will stay with us] and you will probably end up full time. That's how we grow. (Participant \#8)

It was evident from the data that all the participants trained in social work were using some components of the social entrepreneurship process: opportunity identification in social needs, innovative ideas to address unmet needs, innovative programs and services, developing partnerships and collaboration, accepting and facing challenges, building team and collective efforts, revenue generation for financial sustainability, measuring outcomes, and developing and writing business plans. However, in the absence of formal training in social entrepreneurship, most participants (all but three) had difficulty describing this perspective in its entirety and applying it in practice.

For HSPs not trained in social work, the practice of social entrepreneurship included building skills and competencies to be entrepreneurial within organizations, the pursuit of a triple bottom line, taking risks by experimenting and learning from failures, and collaborating with other organizations and using partnerships.

Building core competency ... it wasn't about doing it for them and it wasn't about just telling them about it ... it was trying to help the organization develop a skill set that could be institutionalized that would make them more entrepreneurial. (Participant \#12)

One of my mottos when anybody new comes on board is that we do not have any one way to do things ... Always challenge and always come up with something better... There is always risk with innovation ... I don't believe in failure, it's just that something didn't work so you try something else. (Participant \#14) 


\section{Discussion}

This study contributed to the literature by analyzing how HSPs based in nonprofit organizations practice social innovation, create social value and understand social entrepreneurship, and by responding to the research questions around why, how, and what. Fourteen HSPs participated in the study-10 participants with social work training and four participants trained in other fields. Although there were some apparent differences in their responses, probably owing to their differential training and background, the small sample size warrants additional investigation for developing researchable hypotheses. The first research question pertained to "why" HSPs needed to innovate. "The increased demands on nonprofits' services, coupled with the shrinking supply of public funding for nonprofits, has caused many organizations" to be socially entrepreneurial and innovative (Phills et al. 2008, p. 40). All respondents referenced the challenges in the social, political, and economic environment of their respective HSOs, which created more demand for existing or new services on the one hand, and reduced funding opportunities on the other. More specifically, the increasing requirements from funders, i.e., the greater accountability and demand for measuring outcomes and impact, were particularly challenging for HSPs trained as social workers. As mentioned by Martin and Osberg (2007), HSOs are increasingly being required to demonstrate their worth and sustainable impact. Notwithstanding these challenges and changing landscape of expectations, all respondents tried to not only continue creating social value through existing services (Mulroy and Shay 1997), but several also identified new unmet needs and attempted to address them innovatively. Most HSPs trained as social workers appeared to step outside their comfort zone to try new ideas (Brown 2010).

Respondents appeared to view the changing context as an opportunity instead of a challenge alone. Are opportunities for social innovation and solving social problems created or discovered? Zur (2015) opines that recognizing opportunities in the context is subjective, though the presence of opportunities is objective, and defines opportunity as "situations in which new mean-ends combinations in socio-economic environments can be created or optimized and that hold value over a limited amount of time" (p. 79).

The second part of the research question pertained to how HSPs were socially innovative while creating social value. Contextual challenges did not hinder respondents from continuing to create social value by innovatively responding to new unmet needs, through collaboration, partnerships, and networks, because the locus of innovation was in the system, not in one person or organization (Phillips et al. 2015). Social innovation creation actually occurs within a network or a social system, with a plethora of actors and institutions, and not independently by an organization or a person (Phillips et al. 2015; Rao-Nicholson et al. 2017). Research suggests that organizations with limited resources continue to achieve sustainable impact by working within different types of networks (Wei-Skillern 2010). Different types of networks provide access to local community knowledge, financing, and development opportunities that can reduce risks while promoting social goals (Ratten and Welpe 2011; Wei-Skillern 2010). Networking and brokering tangible (noncash) resources are significant for creating social value through social innovation-exemplified by some respondents-that addresses complex challenges (Moore and Westley 2011).

Respondents partnered with other organizations and parents of children they served to increase the scope of the social value they were creating and also to make the services more sustainable. Essentially by deploying these strategies, respondents ensured that the new ideas or solutions were sustainable (Nikolic 2016), and goals of the organization appeared to play a role in the range of social innovative strategies (Alvord et al. 2004).

Hervieux et al. (2010) propose that involving the beneficiaries in the network cultivates an empowering environment for them and also bolsters the social entrepreneur's ability to co-create solutions. Beneficiaries were involved in one organization for innovatively co-creating new solutions for mental health clients; in another organization, parents of group home residents were mobilized for co-creating resource solutions for the organization. As mentioned by Hamby et al. (2010), being knowledgeable about the local culture and being accepted by community members to address problems 
is important for social innovation success. Participants in this study demonstrated these qualities and capabilities through the processes they followed for creating social value.

Some of the innovative ideas were bifocal in nature, in that they created social value and also involved monetary exchange for the services (Van der Have and Rubalcaba 2016). Respondents also continued to innovate by mobilizing resources in nontraditional fashion by using interns and increasing their reliance on reliable pools of volunteers. They bartered, engaged in space sharing, and also sold their service delivery model for a technical assistance fee. Resource mobilization during innovation and for social value creation is not about accumulating cash or other tangible assets, but about identifying and tapping capabilities to deliver the necessary services (Dees et al. 2001).

For ensuring the financial viability of services, some respondents employed creative marketing strategies, rather nontraditional in nature, and some HSPs with social work backgrounds engaged in learning how to write business plans. HSPs not trained as social workers appeared to be more comfortable with writing business plans. Some HSPs identified new markets for their services-for example, the online delivery of content, providing services to a different population segment. Essentially, respondents were continuously adapting to a changing environment for value creation (Kuratko et al. 2017) and were recognizing opportunities for creating additional social value in the community by deploying innovative strategies and services. Innovation is impacted by an individual's or social entrepreneur's ability to make and see connections between apparently unrelated events and concepts, identify opportunities, and take advantage of them (Munoz-Bullon 2016).

During the social innovation process, respondents either improved their current services, advanced and differentiated their organization from competitors in the marketplace, or improved the internal processes of the organization and modified the larger context for services for children (Baregheh et al. 2009; Moore and Westley 2011). Their efforts produced either tangible or intangible benefits for community wellbeing, and focusing on the sustainability of the innovation and benefits was important to all (Maguirre et al. 2016). Some HSPs, especially those not trained in social work, were more attuned to the "affordable loss" concept (Dew et al. 2009) than others, since engaging in social innovation is not risk-free.

All respondents provided evidence for creating social value-desired social change or impact (Singh 2016) - through the social innovation process, which is central to social entrepreneurship (Lehner 2011). They created value by fulfilling their organization's mission and meeting the needs of their existing clients (e.g., individuals with mental illness, dementia, young adults who had been sexually assaulted, women and children who had experienced abuse). They also created social value by addressing new identified needs through customer feedback by streamlining internal operations of an organization to increase efficiency and greater impact in the community. Additionally, HSPs trained in disciplines other than social work identified new niche markets for their services and products to generate additional revenue streams while creating social value for new market segments. For instance, one respondent creatively used the marketplace to generate funds for agency programs for at-risk youth while also helping them to acquire a skill set that enhanced their livelihood opportunities. Through creative partnerships with other organizations and members in the community, this social innovation venture not only ensured social and economic justice for the program clients, but also created pathways to financial self-sufficiency for the program's operations.

Most likely, respondents also created social value for other stakeholders, e.g., volunteers and interns, by impacting their lives positively through the experience provided within HSOs. Some emphasized the importance of measuring social impact and in doing so attempted to quantify the social value they were creating. Respondents appeared to create some of the following types of social value: financial, political and institutional, human capital, stakeholder collaboration and involvement, and development of relationships leading to community member empowerment (Altinay et al. 2016).

Similar to HSPs trained in social work, HSPs not trained in social work partnered with different organizations and stakeholders (e.g., thrift stores, dentists) to ensure financial sustainability of existing products and services and created social value by modifying contextual structures and processes 
(Singh 2016). Respondents also created social value in a similar fashion to the respondents in the study completed in India (Sundaramurthy et al. 2013), by being market makers or systems innovators. Interestingly, HSPs trained as social workers referenced the social work code of ethics as the driving force for creating social value, and HSPs trained in other fields referenced social and economic justice (components of the code of ethics) as the driving force for creating social value. Even though the latter were not trained in social work, their own moral compass seemed to drive their social value creation efforts, similar to the findings of the Singh (2016) study.

The last question pertained to respondents' understanding of social entrepreneurship. Most HSPs trained in social work identified a few dimensions of the concept (e.g., business plan, income generation) and only three of these respondents identified all dimensions of the concept-opportunity recognition, meeting a social need, social innovation, risk-taking, affordable loss, proactive behaviors, market orientation, social value creation, and social enterprise (Choi and Majumdar 2013; Dees 1998). Essentially, these respondents were familiar with the concept, but did not have a clear understanding of the various dimensions. Conversely, HSPs trained in other disciplines other than social work seemed to have a more comprehensive understanding of the concept.

Most respondents appeared to be practicing as social bricoleurs (Zahra et al. 2009), in that they were identifying new unmet needs and innovatively addressing them in the local community. They appeared to be deploying various components of the social entrepreneurship process described earlier. HSPs trained as social workers provided adequate evidence that they were using various components of social entrepreneurship process, though at different levels: opportunity identification for meeting social needs, innovative ideas for addressing unmet needs, innovative programs and services, developing partnerships and collaboration, accepting and facing challenges, building team and collective efforts, generating revenue for financial sustainability, measuring outcomes, and developing and writing business plans. HSPs not trained in social work appeared to be employing more components of the process-including risk-taking, experimentation, learning from failures, and building a financial sustainability model for social innovation-than those trained in social work. Most respondents appeared to also be entrepreneurial leaders-with a transformational orientation-who deal with dynamic market opportunities and challenges and also exhibit caring, vision, and self-confidence (Sousa 2018).

The main limitation of this study is the sample size. The goal of the study was not to generalize, but to understand how HSPs created social value through social innovation and how they perceived and practiced social entrepreneurship. Also, given the very small sample size of HSPs not trained in social work, it is equally difficult to develop propositions related to some of the differences noted in the data. The study contributed to the literature on social innovation, social value creation, and social entrepreneurship, notwithstanding the aforementioned limitation-since there is limited research on these concepts, especially among HSP trained in social work, and almost no comparison with those trained in other fields.

\section{Conclusions, Implications, and Recommendations}

In conclusion, all HSPs were creating various types of social value, and some were increasing the scope of the value creation by entering new markets. They were deploying socially innovative strategies, almost intuitively, to continue creating social value. Some HSPs realized that they were being socially entrepreneurial by creating social value, and hence deployed more components of the process than others (Choi and Majumdar 2013). Choi and Majumdar (2013) mentioned five components of the SE model: (1) social value creation, (2) the social entrepreneur, (3) the SE organization, (4) market orientation, and (5) social innovation. The present study supports this model in the context of HSPs and HSOs. Based on our findings, we propose replacing two components of the SE model-the SE organization and the social entrepreneur-with HSO and HSP, respectively, because nonprofit managers are being called upon to facilitate innovative change and design and develop effective programs (NWSM competencies). By extending the conceptual framework of SE model to encompass 
HSOs and HSPs, researchers and practitioners can better understand the relationships between market orientation, SI, HSO, and HSP in the process of SV creation.

In a global, dynamic context, proactive approaches-instead of residual or remedial approaches-should be used by HSPs for addressing complex social issues (Tan 2012). This study demonstrated that HSPs naturally, and almost intuitively, create social value and often default to being socially innovative and entrepreneurial, especially when contextual changes (e.g., increased accountability; a reduction in funding) create challenges that can be treated as opportunities. Even without formal training, participants stumbled upon the social innovation or social entrepreneurial perspective and process in order to fulfill the mission of the HSO. They may not formally use the term "social value creation," but through their practices, processes, and services, they were almost automatically creating value, and serving as change agents. There is not enough evidence to suggest that HSPs trained as social workers employed drastically different approaches from those not trained in the social work discipline; however, there are some differences that need to be investigated further.

Essentially, future qualitative research should explore the processes used by HSPs, from different fields and levels in the organization, for creating social value through social innovation. Additionally, differences in understanding and practicing social entrepreneurship, based on the academic training of HSPs, should be investigated. Since social entrepreneurship is still a nascent field, exploring and understanding social value creation processes from different theoretical perspectives needs to continue within HSOs.

Based on our findings, we recommend that the graduate curriculum in business, public administration, law, social work, and other related fields should formally include concepts, principles, and behaviors related to social innovation and entrepreneurship. Additionally, internships and practicums in these fields can also incorporate these principles into student learning. Furthermore, the curriculum at the graduate level and CEU workshops should include concepts such as cross-sector partnership development, business plans, measuring social value, and how to participate in dialogue around these concepts when they are initiated by business, nonprofit, and public sector organizations. As Nandan and Scott (2013) recommend, since social entrepreneurship is transdisciplinary in nature, more dual degree programs (e.g., MSW/MBA) and certificates in social entrepreneurship should be initiated within higher education.

Author Contributions: The first author was responsible for creation of the research instrument and contacting administrative staff in nonprofit organizations in the Midwest region for purposes of the study. The other two authors were part of the qualitative data analysis process and interpretation of study findings.

Funding: This research received no external funding.

Conflicts of Interest: The authors declare no conflict of interest.

\section{References}

Altinay, Levent, Marianna Sigala, and Victoria Waligo. 2016. Social Value Creation through Tourism Enterprise. Tourism Management 54: 404-17. [CrossRef]

Alvord, Sarah H., L. David Brown, and Christine W. Letts. 2004. Social Entrepreneurship and Societal Transformation: An Exploratory Study. Journal of Applied Behavioral Science 40: 260-82. [CrossRef]

Auerswald, Philip. 2009. Creating Social Value. Stanford Social Innovation Review 7: 50-55.

Baregheh, Anahita, Jennifer Rowley, and Sally Sambrook. 2009. Towards a Multidisciplinary Definition of Innovation. Management Decision 47: 1323-39. [CrossRef]

Boris, Elizabeth T., Erwin de Leon, Katie Roeger, and Milena Nikolova. 2010. Human Service Nonprofits and Government Collaboration: Findings from the 2010 National Survey of Nonprofit Government Contraction and Grants. Washington, DC: Urban Institute.

Brown, Louise. 2010. Balancing Risk and Innovation to Improve Social Work Practice. British Journal of Social Work 40: 1211-28. [CrossRef]

Caldwell, Nigel D., Jens K. Roehrich, and Gerard George. 2017. Social Value Creation and Relational Coordination in Public-Private Collaborations. Journal of Management Studies 54: 906-28. [CrossRef] 
Choi, Nia, and Satyajit Majumdar. 2013. Social Entrepreneurship as an Essentially Contested Concept: Opening a New Avenue for Systematic Future Research. Journal of Business Venturing 29: 363-76. [CrossRef]

Clark, Cheryl, and Linda Brennan. 2016. Social Entrepreneurship: A Global Model for Evaluating Long-term Impact. International Journal of Entrepreneurship 20: 1-15.

Corner, Patricia Doyle, and Marcus Ho. 2010. How Opportunities Develop in Social Entrepreneurship. Entrepreneurship Theory and Practice 34: 635-59. [CrossRef]

Dacin, Peter A., Tina M. Dacin, and Margaret Matear. 2010. Social Entrepreneurship: Why We Don't Need a New Theory and How We Move Forward from Here. Academy of Management Perspectives 24: 37-57. [CrossRef]

Dees, J. Gregory, and Beth Battle Anderson. 2003. Sector-bending: Blurring Lines between Nonprofit and For-Profit. Society 40: 16-27. [CrossRef]

Dees, J. Gregory, Jade Emerson, and Peter Economy. 2001. Enterprising Nonprofits: A Toolkit for Social Entrepreneurs. New York: John Wiley \& Sons, Inc.

Dees, J. Gregory. 1998. Enterprising Nonprofits. Harvard Business Review 76: 54-67. [PubMed]

Dew, Nicholas, Saras Sarasvathy, Stuart Read, and Robert Wiltbank. 2009. Affordable Loss: Behavioural Economic Aspects of the Plunge Decision. Strategic Entrepreneurship Journal 3: 105-26. [CrossRef]

Fawcett, Barbara, and James South. 2005. Community Involvement and Primary Care Trusts: The Case for Social Entrepreneurship. Critical Public Health 15: 191-204. [CrossRef]

Gibelman, Margaret, and Rich Furman. 2008. Navigating Human Service Organizations, 2nd ed. Chicago: Lyceum Book Inc.

Given, Lisa M. 2008. The SAGE Encyclopedia of Qualitative Research Methods. Thousand Oaks: SAGE Publications, Inc., vol. 2. [CrossRef]

Gray, Rob. 2006. Social, Environmental and Sustainability Reporting and Organizational Value Creation: Whose Value? Whose creation? Accounting, Auditing \& Accountability Journal 19: 793-819. [CrossRef]

Greblikaite, Jolita, Włodzimierz Sroka, and Juris Grants. 2015. Development of Social Entrepreneurship in European Union: Policy and Situation of Lithuania and Poland. Transformations in Business E Economics 14: 376-96.

Hamby, Anne, Meghan Pierce, and David Brinberg. 2010. A Conceptual Framework to Structure Research in Strategic and Social Entrepreneurship. Journal of Asia-Pacific Business 11: 166-78. [CrossRef]

Harding, Rebecca. 2007. Understanding Social Entrepreneurship. Industry and Higher Education 21: 73-84. [CrossRef]

Hasenfeld, Yeheskel. 2015. What Exactly is Human Services Management? Human Service Organizations: Management, Leadership E Governance 39: 1-5. [CrossRef]

Herrera, Maria, and Baltazar Elena. 2015. Creating Competitive Advantage by Institutionalizing Corporate Social Innovation. Journal of Business Research 68: 1468-74. [CrossRef]

Herrera, Maria, and Baltazar Elena. 2016. Social Innovation for Bridging Societal Divides: Process or Leader? A Qualitative Comparative Analysis. Journal of Business Research 69: 5241-47. [CrossRef]

Hervieux, Chantal, Eric Gedajlovic, and Marie-France B. Turcotte. 2010. The Legitimization of Social Entrepreneurship. Journal of Enterprising Communities People and Places in the Global Economy 4: 37-67. [CrossRef]

Jarman-Rohde, Lily, Joann McFall, Patricia Kolar, and Gerald Strom. 1997. The Changing Context of Social Work Practice: Implications and Recommendations for Social Work Educators. Journal of Social Work Education 33: 29-46. [CrossRef]

Jaskyte, Kristina, Olivia Amato, and Rachel Sperber. 2018. Foundations and Innovation in the Nonprofit Sector. Nonprofit Management and Leadership 29: 47-64. [CrossRef]

Jiao, Hao. 2011. A Conceptual Model for Social Entrepreneurship Directed Toward Social Impact on Society. Social Enterprise Journal 7: 130-49. [CrossRef]

Konda, Iva, Jasmina Starc, and Baabara Rodica. 2015. Social Challenges are Opportunities for Sustainable Development: Tracing Impacts of Social Entrepreneurship through Innovations and Value Creation. Economic Themes 53: 215-33. [CrossRef]

Kotter, John P. 2012. Leading Change. Boston: Harvard Business Review Press.

Kroeger, Arne, and Christiana Weber. 2014. Developing a Conceptual Framework for Comparing Social Value Creation. Academy of Management Review 39: 513-40. [CrossRef] 
Kuratko, Donald F., Jeffrey S. McMullen, Jeffrey S. Hornsby, and Jackson Chad. 2017. Is Your Organization Conducive to the Continuous Creation of Social Value? Toward a Social Corporate Entrepreneur Scale. Business Horizon 60: 271-83. [CrossRef]

Lehner, Othmar M. 2011. The Phenomenon of Social Enterprise in Austria: A Triangulated Descriptive Study. Journal of Social Entrepreneurship 2: 53-78. [CrossRef]

Lisetchi, Mihai, and Laura Brancu. 2014. The Entrepreneurship Concept as a Subject of Social Innovation. Procedia-Social and Behavioral Sciences 124: 87-92. [CrossRef]

Maguirre, Mario, Ruelas Vazquez, Camacho Gloria, and Garcia Torre De La Consuleo. 2016. Women Empowerment through Social Innovation in Indigenous Social Enterprises. São Paulo: Universidade Presbiteriana Mackenzie, RAM-Revista de Administracao Mackenzie. [CrossRef]

Mair, Johanna, and Oliver Schoen. 2007. Successful Social Entrepreneurial Business Models in the Context of Developing Economies: An Explorative Study. International Journal of Emerging Markets 2: 54-68. [CrossRef]

Martin, Roger L., and Sally Osberg. 2007. Social Entrepreneurship: The Case for Definition. Stanford Social Innovation Review 5: 30-39.

Moore, Michele-Lee, and Frances Westley. 2011. Surmountable Chasms: Networks and Social Innovation for Resilient Systems. Ecology and Society 16: 5. [CrossRef]

Moulaert, Frank, Flavia Martinelli, Erik Swyngedouw, and Sara Gonzalez. 2005. Towards Alternative Models of Local Innovation. Urban Studies 42: 1969-90. [CrossRef]

Mulroy, Elizabeth A., and Sharon Shay. 1997. Nonprofit Organizations and Innovation: A Model of Neighborhood-based Collaboration to Prevent Child Maltreatment. Social Work 42: 515-24. [CrossRef]

Munoz-Bullon, Fernando. 2016. The state of innovation and entrepreneurship research. Administrative Science 6: 6. [CrossRef]

Nandan, Monica, and Patricia A. Scott. 2013. Social Entrepreneurship and Social Work: The Need for a Transdisciplinary Education Model. Administration in Social Work 37: 257-71. [CrossRef]

Nandan, Monica, Tricia Bent-Goodley, and Gokul Mandayam. 2019. Social Entrepreneurship, Intrapreneurship and Social Value Creation: Relevance for Contemporary Social Work Practice. Washington, DC: NASW Press.

National Organization for Human Services (NOHS). 2019. Available online: https://www.nationalhumanservices. org/ (accessed on 20 March 2019).

Nikolic, Predrag K. 2016. Interactive Environments: Opportunities for Social Innovation and Public Health Initiatives. EIRP Proceedings 11: 300-10.

Ormiston, Jarro, and Richard Seymour. 2011. Understanding Value Creation in Social Entrepreneurship: The Importance of Aligning Mission, Strategy and Impact Measurement. Journal of Social Entrepreneurship 2: 125-50. [CrossRef]

Pärenson, Tuuli. 2011. The Criteria for a Solid Impact Evaluation in Social Entrepreneurship. Society and Business Review 6: 39-48. [CrossRef]

Patton, Michael Quinn. 2001. Qualitative Research and Evaluation Methods, 2nd ed. Thousand Oaks: Sage Publications.

Perrini, Francesco, Clodia Vurro, and Laura A. Costanzo. 2010. A Process-based View of Social Entrepreneurship: From Opportunity Identification to Scaling-up Social Change in the case of San Patrignano. Entrepreneurship $\mathcal{E}$ Regional Development 22: 515-34.

Phillips, Wendy, Hazel Lee, Abby Ghobadian, Nicholas O’Regan, and Peter James. 2015. Social Innovation and Social Entrepreneurship: A Systematic Review. Group \& Organization Management 40: 428-61. [CrossRef]

Phills, James A., Jr., Kriss Deiglmeier, and Dale T. Miller. 2008. Rediscovering Social Innovation. Stanford Social Innovation Review 6: 34-43.

Pol, Eduardo, and Simon Ville. 2009. Social Innovation: Buzz Word or Enduring Term? The Journal of Socio-Economics 38: 878-85. [CrossRef]

Polonsky, Michael Jay, and Stacey Landreth Grau. 2008. Evaluating the Social Value of Charitable Organizations: A Conceptual Foundation. Journal of Macromarketing 28: 130-40. [CrossRef]

Rao-Nicholson, Rekha, Tim Vorley, and Zaheer Khan. 2017. Social Innovation in Emerging Economies: A National Systems of Innovation Based Approach. Technological Forecasting \& Social Change 121: 228-37. [CrossRef]

Ratten, Vanessa, and Isabell M. Welpe. 2011. Special Issue: Community-based, Social and Societal Entrepreneurship. Entrepreneurship \& Regional Development 23: 283-86. [CrossRef] 
Rego, Lyndon, and Aparna Bhandary. 2006. New Model: A Social Entrepreneur Changes the Landscape. Leadership in Action 26: 8-11. [CrossRef]

Roper, Juliet, and George Cheney. 2005. Leadership, Learning and Human Resource Management: The Meanings of Social Entrepreneurship Today. Corporate Governance 5: 95-104. [CrossRef]

Schmitz, Björn, and Thomas Scheuerle. 2012. Founding or Transforming? Social Intrapreneurship in Three German Christian-based NPOs. ACRN Journal of Entrepreneurship Perspectives 1: 13-36.

Seelos, Christian, and Johanna Mair. 2005. Social Entrepreneurship: Creating New Business Models to Serve the Poor. Business Horizons 48: 241-46. [CrossRef]

Sensoy Bahar, Ozge. 2017. A Promising Partnership: Uncovering the Middle Ground between Social Innovation and Social Work. Research on Social Work Practice 27: 131-33. [CrossRef]

Shockley, Gordon E., and Peter M. Frank. 2011. Schumpeter, Kirzner, and the Field of Social Entrepreneurship. Journal of Social Entrepreneurship 2: 6-26. [CrossRef]

Short, Jeremy C., Todd W. Moss, and G. Tom Lumpkin. 2009. Research in Social Entrepreneurship: Past Contributions and Future Opportunities. Strategic Entrepreneurship Journal 3: 161-94. [CrossRef]

Singh, Archana. 2016. The Process of Social Value Creation: A Multiple-Case Study on Social Entrepreneurship in India. New Delhi: Springer.

Sousa, Maria Jose. 2018. Entrepreneurship Skills Development in Higher Education Courses for Teams Leaders. Administrative Science 8: 18. [CrossRef]

Stoesz, David. 2011. Book and Technology Review. [Review of the book Social entrepreneurship: What everyone needs to know, by D. Bornstein \& S. Davis]. Research on Social Work Practice 21: 373-77.

Sundaramurthy, Chamu, Martina Musteen, and Amy E. Randel. 2013. Social Value Creation: A Qualitative Study of Indian Social Entrepreneurs. Journal of Developmental Entrepreneurship 18: 1-20. [CrossRef]

Tan, Ngoh-Tiong. 2012. Social Entrepreneurship: Challenge for Social Work in a Changing World. Asia Pacific Journal of Social Work and Development 14: 87-98. [CrossRef]

Van der Have, Robert P., and Luis Rubalcaba. 2016. Social Innovation Research: An Emerging Area of Innovation Studies? Research Policy 45: 1923-35. [CrossRef]

Weerawardena, Jay, and Gillian Sullivan Mort. 2006. Investigating Social Entrepreneurship: A Multidimensional Model. Journal of World Business 41: 21-35. [CrossRef]

Weerawardena, Jay, and Gillian Sullivan Mort. 2012. Competitive Strategy in Socially Entrepreneurial Nonprofit Organizations: Innovation and Differentiation. Journal of Public Policy \& Marketing 31: 91-101.

Wei-Skillern, Jane. 2010. Networks as a Type of Social Entrepreneurship to Advance Population Health. Preventing Chronic Disease: Public Health Research, Practice, and Policy 7: 1-5.

Zahra, Shaker A., Eric Gedajlovic, Donald O. Neubaum, and Joel M. Shulman. 2009. A Typology of Social Entrepreneurs: Motives, Search Processes and Ethical Challenges. Journal of Business Venturing 24: 519-32. [CrossRef]

Zietlow, John. T. 2001. Social Entrepreneurship: Managerial, Finance and Marketing Aspects. Journal of Nonprofit $\mathcal{E}$ Public Sector Marketing 9: 19-25. [CrossRef]

Żur, Agnieszka. 2015. Social Problems as Sources of Opportunity: Antecedents of Social Entrepreneurship Opportunities. Entrepreneurial Business E Economics Review 3: 73-87. [CrossRef]

(C) 2019 by the authors. Licensee MDPI, Basel, Switzerland. This article is an open access article distributed under the terms and conditions of the Creative Commons Attribution (CC BY) license (http://creativecommons.org/licenses/by/4.0/). 